\title{
Man and His Environment in Norway
}

\section{Bertha Henderson}

To cite this article: Bertha Henderson (1911) Man and His Environment in Norway, Journal of Geography, 10:2, 46-51, DOI: 10.1080/00221341108985639

To link to this article: http://dx.doi.org/10.1080/00221341108985639

曲 Published online: 20 May 2008.

Submit your article to this journal $\pi$

Џll Article views: 3

Q View related articles $₫$ 


\title{
MAN AND HIS ENVIRONMENT IN NORWAY
}

\author{
By BERTHA HENDERSON,
} Whitewater, Wis.

$\mathrm{I}^{\mathrm{N}}$ this short article I shall not attempt to explain from a geographical standpoint the intricacies of Norwegian history, literature, and character. It is my aim only to show in a broad general way the conditions that surround the people and how the people have either adapted themselves to environment or made use of their surroundings to promote their general welfare.

The southern tip of Norway lies about five miles south of the 58th parallel, or in the same latitude with Sitka. From this point the land stretches northeast 1100 miles until the last of it lies almost on the top of the world, within less than 1200 miles of the North Pole, while onethird of the country is on the cool side of the Arctic Circle. Its greatest width, which is in the southern part, is about 310 miles. The width lessens toward the north until in Nordland it is less than six miles. On the east lies Sweden and to the west are the Atlantic Ocean and the drift of the Gulf Stream. The British Isles are only about 500 miles across the North Sea, and Denmark is just over the Skager-Rak; within easy steaming distance to the south, are Belgium and the Netherlands with their dense populations.

The surface of Norway is a huge block of primary rock made up almost entirely of crystalline formations, granite, schist, gneiss, etc. In a few places sedimentary rocks have been discovered recently. The most notable of these are, first, an area to the north and east of Christiania, along the Bergen Railway where outcrops of alternating bands of black and white limestone of the Silurian formation occur and, second, on the banks of Lake Mjosen and near Trondhjem Stift. None of these overlying formations are of large area, and if at early geological times they covered the country all traces of them have been effectually scoured away. There are no distinct mountain ranges but in places, notably in the Romsdal, the gneiss, the oldest of the formations, towers in sheer bare pinnacles 5000 to 6000 feet in elevation. The backbone or crest of the plateau follows closely the line between Norway and Sweden until opposite Trondhjem. There it swings off to the southwest in the direction of Stavanger. The eastern side slopes gently into the lowlands of Sweden, but the western side descends abruptly into the Atlantic Ocean. The entire mass of twisted, contorted rocks has been faulted, jointed, and overthrust from the forces within the earth, and scoured and worn on the surface by the agents of erosion. On the southeast long, sloping, wide valleys and tame, rounded hills lead off toward the lowland, but on the west the massive block of rock has been gashed by deep trenches thousands of feet below 
sea level and extending back into the mainland for scores of miles. These fiords are separated by flat-topped plateaus. Along the Sogne Fiord and its branches the Aurlands and Nearo, the Bejteln headland, and the pointed Gjeitegg rise sheer from sea level more than 3000 feet and for hundreds of feet their sides have been so effectually icepolished that not a grain of soil has found lodgment since the retreat of the glacier. Some of the rocky walls are separated from the waters of the fiords by narrow strips of low land, and in other places deltas and alluvial fans have been built of the waste from tributary valleys. In many instances the flat tops of the blocks between the fiords are covered with sheets of ice which rest on the surface like huge tablecloths and send tongues of ice in all directions down the valleys. Some of these valley glacriers descend to within 268 feet of sea level. These ice masses are the remnants of the ice cap that formerly covered the entire country. At the present time, as the sheets push slowly out over the plateau, or the valley glacriers plow down the valleys, they filch from the land tons of rock which they grind into sand or clay or boulders and strew along their sides or deposit at their terminals, and everywhere over the land, ancient moraines are found and make up the only soil which covers the bed rock. In the west the lateral moraines line either side of the narrow valleys and in the broader lower eastern part the drift is scattered irregularly over the strongly undulating surface.

The high latitude and elevated surface of Norway suggest a rigorous climate, but the prevailing westerly winds and the warm waters of the Gulf Stream Drift counteract the influence of latitude and altitude. The annual range of temperature on the west coast at Stavanger is from 34.70 in January to 55.40 in July and as far north as Trondhjem only the upper ends of the fiords freeze. The winters are long and mild and the summers short and cool. Farther to the east the range increases until at Christiania and Lillehammer the winters are long and cold and the summers short and hot. The August days in Kongsberg and Christiania are as warm as the July days in Munich and Paris. The rainfall in Bergen averages about 75 inches; that of Christiania about 22 inches, but nowhere is there insufficient moisture for vegetation. The story is told that in Bergen horses shy at men without umbrellas. During the summer months in south Norway the sun rises between two and three o'clock in the morning and sets about ten or eleven at night; farther north the nights dwindle to an hour or two of twilight. During the winter the opposite is true, a few hours of daylight and a long night. Owing to the nature of the bed rock and the thin coating of mantle rock, the copious rainfall is held on the surface in numerous rock basins or runs away in countless streams. The entire surface is dotted with lakes, large or small, high or low, strung to- 
gether by the connecting water courses. The uneven surface and the resistant rock account for the universal presence of waterfalls.

No large rivers are found on the steep western slope, and the Glommen is the only one that attains any size on the eastern side. The coastline is long and irregular, faced on the west by the bare rock walls of the mainland and on the east and south by the gently sloping forested lands. Fragments of the mainland, in an indescribable jumble of islets and headlands, make an immense archipelago called the Skjaergaard, which shelters navigation along the entire coast. The shore line is made up of a succession of harbors, and the warm, quiet waters of the fiords and sheltered nooks abound in fish. Seventy-five per cent of the total area is unproductive and twenty-two per cent of the remainder is forested. Forests of pine, spruce, and fir clothe the slopes to the snow line, and these are interrupted by stretches of maple, birch, ash, rowan, and beech. Where the forests have been cleared away and in the vales, the scanty soil produces a rich luscious grass. Every field and slope is bright with the common flowers. Buttercups, johnny-jump-ups, forget-me-nots, harebells grow in wild confusion, while every shady nook presents a fern hunter's paradise. At the present time the most characteristic wild animal is reindeer. Large herds of these useful beasts have been half domesticated by the Lapps and furnish their sole support. A fine species of elk and a few red deer furnish sport for the huntsman, and the government offers a bounty for the pelts of bear, wolf, lynx, and glutton. The finest of the wild fowl is the capercailzie, then the ptarmigan and hazel grouse. Within the Arctic Circle the eider duck thrives and is probably the most valuable of all the wild fowl.

Such is the setting of the country,-three-fourths of the land unproductive, nearly one-fourth covered with forests, the only fertile soil collected in the narrow valleys, long winters with many hours of darkness and but few of light each day, but little mineral wealth, a coast with many fine harbors, and surrounding waters filled with fish. The problem now is to show how these conditions have affected the occupations, development, and prosperity of the people.

Let us consider, first, the climate, which we find bracing and invigorating. The people are not enervated by extreme heat nor are they made lazy by a bountiful nature. What they live upon they must wring with effort from the stubborn land. On the other hand, the hammer of environment is not so hard that every energy is exhausted in securing meager food, sheiter, and clothing. The Norseman in his struggle for existence brings into play every faculty, but at the same time there is some leisure for the growth of culture and for progress. The wits are sharpened by use but are not dulled by over exhaustion. The ironbound coast and the unproductive hinterland early drove the primitive Norseman to the sea for 
his food. The sheltered waters of the fiords and the passages in the Skjaergaard were excellent training fields for the early navigators. The nearby islands were tempting goals for the most venturesome. Then it was but a step to those farther out, and this demanded a more seaworthy craft. The better ships and bolder spirits thus developed soon carried the sailors to the nearby countries, then to France, to Greece, to Iceland, and finally to America. Beyond a doubt, the barren lands, the excellent harbors, and the skirting islands were the controlling factors in producing the early Norsemen and the Vikings. Today with her small area and comparatively small population, Norway ranks in the class of navigators with Great Britain, Germany, and the United States. No other city in the world, unless it be Aberdeen, outranks Bergen in the amount of fish handled every year. Thousands of men are employed daily in catching and caring for the fish. Whole cargoes of codliver oil and cod, herring, oysters, and lobsters are shipped out every year, and fish is one of the staple articles on every Norwegian table. Among the early maritime nations, Norway takes equal rank with Phoenicia and Greece. Next to fishing and navigation as occupations, the industries of the forests take high rank. The slow growth of the Norway pine gives the wood a tough quality which makes it valuable as lumber and timbers for ships. The great ship building yards of the British Isles and Germany create a ready market for the supply. The numerous streams carry the logs from forest to mill or to coast with but little effort and expense. The abundant waterpower saws the logs into boards or grinds the blocks into paper pulp. The houses are built of timbers because the timbers are more plentiful, more adaptable, more accessible than any other building material. Thirty thousand men and boys make their living through the forest and forest products because the conditions of the country make these occupations inevitable.

The mineral wealth of the country is meager. Rich silver veins near Knogsberg and copper mines near Trondhjem are the only deposits so far discovered that yield ores in paying quantities. The silver has been worked since the $1 \%$ th century, and the inhabitants excel as silversmiths.

The scanty soil on the rough surface will not yield grain sufficient to support the population. In many places the summers are not long enough to ripen the grain. But the soil does yield grass and fodder, which carefully harvested and fed to cattle, shows a good return; hence the universal dairy business and the quantities of milk and butter and the numerous varieties of cheese. Also from these conditions come the quaint and romantic custom of saeters or summer mountain pastures. We may attribute the small per cent of railroad mileage to the rough country and not to the lack of enterprise and progress on the part of the people. In a land where lakes and fiords abound and where easy and effective water transportation has been establish for centuries, men will not build rail- 
roads that call for a great outlay of capital, supreme engineering skill, and infinite labor. Moreover, why does one want to ride on a rumbling dirty train through dark tunnels and along hair raising precipices when he may glide along in a boat over the quiet glassy waters of the fiords and lakes?

In the early times, the tribes or clans lived insolated lives in the remote valleys. Intercourse with each other was rare; life was hard and the strongest succeeded. A spirit of independence, of sturdy self-reliance, and of democracy developed very early. For many centuries the country was gaverned by numerous petty kings, each in his own system of valleys and separated from his neighbor by the bleak plateau. These kingdoms were not united until late in the 10th century and were never held together by a strong bond until the safety of the land against outside enefies demanded unity. Today the people are united by a strong bond of partriotism, but the old independence and democracy still prevail.

The wild strenuous life of the hunter, the sailor, the fisher furnished tales of adventure and the struggles between the petty kings made heroes and tales of romance. During the long winter nights the families gathered about the roaring wood fires and the best story tellers recounted their experiences or gave the reminiscences of their fathers. Out of this custom grew a prose literature of vigorous and realistic character. Sometimies the tales were given in the rude measures of the times and chanted in rhythm, the first poetry. The compelling, pure, strong literature of Bjornson and Ibsen did not burst forth in full fruit but is the growth of ages.

The intercourse with other nations through the Norsemen and Vikings and later through the navigators and traders lead to an early progressive education which has prevailed ever since, in spite of the ups and downs of government and history. I do not claim that geographical conditions are alone responsible for the fact that Norway has as small a percentage of illiteracy as any country in the world today, but I think we may say that these conditions have had some responsibility in the matter. Let us carry out the same thought in looking at the character of the native. $\mathrm{He}$ is superstitious; even the best of them half believe in trolls, faries, and gnomes, and why should they not? At least one half of the land is wilderness, peopled with mysterious beings; less than half the year has long sunny days when nature smiles and is kind, and more than half when the nights are long and cruel and the days cold and hard; gaining a livelihood in the early times was always attended with hardship and frequently with death; is it strange that the people sought explanation in the supernatural and endeavored to propitiate an unfeeling nature?

I have already shown how his independence, democracy, and patriotism were fostered by his surroundings. In a climate like this even the recreation must be energetic. No Norwegian would be content to spend 
his leisure sitting on a hot stone in the white glare of the sun strumming a guitar. He must leap and run and slide, dance and shout in keeping with the wildness of the land and the tingling atmosphere. Perhaps the history, literature, music and character of man in Norway do not show the causal relations so strikingly as do the occupations and material prosperity of the people, but every one of these features and many others in greater or lesser degree bear the stamp of environment.

\section{LAYING THE FMPHASIS IN TEACHING THE GEOGRAPHY OF ASIA}

By R. H. WHITBECK, University of Wisconsin, Madison

DHYSICALI,Y Europe and Asia form a single continent. In every other particular they are as far apart as the East is from the West. Europe seeks intercourse with all nations; Asia, until compelled to change, opposed such intercourse. Europeans are colonizers, conquerors, traders, and travelers. Comparatively few Asiatics ever go outside of their own provinces. Asiatics do as their fathers have done for two or three thousand years. Rural life in Illinois has changed more in 25 years than it has in Syria since the days of Solomon or in Interior China since Confucius.

Strictly geographical influences-climate, coast line, topography, situation-have exerted a strong influence upon the development of European nations. Such influences are of necessity, operative in Asia, especially the fact that the only parts of Asia capable of supporting a large population are separated from Europe by one or two thousand miles of desert. The isolation of India, China and Japan has favored the establishment of fixed social and religious convictions which blocked progress. The Caste System, contempt for things foreign, exclusiveness, ancestor-worship, have left their impress on Asiatic peoples. But Asia is awaking. The next hundred years are likely to be fraught with the most significant changes that any continent has experienced in that length of time.

We study Europe as a laboratory where men are busy, increasing knowledge, increasing productivity, improving processes, extending influence. Europe is a continent of factories, railroads, schools, armies and fleets. Asia is a museum, the repository of ancient customs, depressing religions, and antiquated methods.

In studying the geography of Asia, I believe the aim is not so much to memorize facts as to get pictures; to gain realistic impressions of the people, not uncivilized, but differently civilized. The foreign commerce of Asiatic countries is small, and calls for no particular emphasis. The leading five commercial nations of Asia all put together have less foreign 